\title{
Democracy in a globalised world: Case study of the Gezi Park protests
}

\author{
MAXWELL PHILLIS
}

\section{Abstract}

This article considers the democratising influence of globalisation on states and individuals. Highlighting the contested definitional scope of globalisation, it presents a detailed analysis of competing explanatory frames and explains their influence on attempts to assess the democratising influence of globalisation. It applies these theoretical frames to a case study of the 2013 Gezi Park protests in Turkey, demonstrating mixed support for both models. It concludes by presenting a partial way forward for overcoming the limitations observed in the transformationalist understanding of globalisation and distributed decision-making.

\section{Introduction}

The contemporary trends of democratisation and the acceleration of globalisation since the end of the Cold War have received much attention across many disciplines. ${ }^{1}$ It seems intuitive that there could be some relationship between the two phenomena, but what is it and how can we assess it? In this article, I attempt to address these broader questions by assessing the democratising influence of globalisation on states and individuals. In particular, I argue that while globalisation increases alternative avenues for representation and engagement that depart from the traditional national/ representative model, these forums require reform to maximise their democratising potential.

I assess the accessibility of democratic representation in a globalising paradigm by considering qualitative indicators of democracy, rather than holding elected state governments as the central unit of analysis. By doing this, I hope to capture a broader array of potentially democratising developments without unnecessarily privileging those changes that fit within the paradigm of national representative democracy and the traditional state. To do this, I look for changes in formal and informal

1 Helen Milner and Bumba Mukherjee, 'Democratisation and Economic Globalisation' (2009) 12 Annual Review of Political Science 163, 163. 
avenues for political representation in unconsolidated democracies that are driven by globalisation, and ask whether they increase the scope for democratic expression by people within those countries. This approach requires a careful definition of 'globalisation' and 'democratisation', which the following section will present. Further, questions of where these changes are occurring and for whom will also be addressed.

This article is in three parts. First, I present a critical analysis of existing literature defining the concepts of globalisation and democratisation. I argue here that conceptual developments in globalisation literature erode traditional conceptions of state-centric democratisation, while creating opportunities for greater transnational representation of individual preferences. Second, I apply two conceptions of democratisation to the case study of Turkey's 2013 Gezi Park protests, focusing on the relative representational power of global governance institutions and state-based democratic institutions. Finally, I develop on themes identified in the case study and argue that while globalisation has increased the scope for the representation of individual and collective interests beyond state governments, it is necessary to develop new approaches to public accountability for their democratising power to be fully realised. The article concludes that a 'transformationalist' understanding of globalisation presents new, though imperfect, mechanisms for democratising political interactions.

\section{Expanding conceptions of democratic representation}

Both globalisation and democratisation are deeply contested concepts. This section critically analyses the existing literature to develop working definitions of these terms for later application to the case study, and to situate this article within current debates. First, I assess the competing conceptions of globalisation, finding that a definition focusing on the unique interconnectedness of multiple public and private spheres most accurately captures the distinguishing features of the phenomenon. Second, I consider the literature on democratisation, with reference to the competing positions of state-based and supranational mechanisms of political representation. Finally, I discuss the interaction between the two concepts and identify challenges that prevent synthesising the two phenomena using a consistent frame of reference.

\section{Interpreting globalisation}

Defining the phenomenon of globalisation is central to this investigation, yet it is contested in almost every dimension. When considering what exactly is being globalised, Stiglitz conceives of globalisation as the process of economic integration of people and countries through the increasing flow of goods, services, capital, 
labour and knowledge across borders. ${ }^{2}$ This understanding is typical of authors who privilege internationalising economic integration as their explanatory frame for globalisation. For example, in assessing the evolving regulatory framework of economic globalisation, Urpelainen adapts Dresner's definition of the concept as 'the removal of physical obstacles to international trade and investment'. ${ }^{3}$ Similarly, O'Rourke and Williamson argue that globalisation is not a new phenomenon when assessed by the metric of international commodity trade. ${ }^{4}$ These applications of an economic framework of globalisation effectively capture their research target, but discount the multitude of other spheres that may simultaneously be globalising. This leads to an unnecessarily truncated view of the phenomenon.

Held and colleagues conceive of globalisation much more broadly. They describe it as 'the widening, deepening and speeding up of worldwide interconnectedness in all aspects of contemporary life. ${ }^{5}$ This difference in emphasis has significant implications for the form that globalisation takes under these two conceptions. Scholte too rejects a purely economic definition of globalisation, ${ }^{6}$ noting, like Held and others, that the conceptual novelty of globalisation lies in the depth of the interconnections between people and across spaces. ${ }^{7}$ Supporting his claim, Scholte develops a typology of four descriptive ideals of globalisation. ${ }^{8}$ In particular, he highlights literature applying liberalisation, internationalisation, universalisation and westernisation/modernisation as frames for understanding globalisation. ${ }^{9}$ $\mathrm{He}$ argues that these conceptions are 'redundant', claiming that they simply couch pre-existing analytical frameworks in the language of globalisation, ${ }^{10}$ thus missing the conceptual novelty of globalisation. He presents the supraterritoriality of social relations between people, across spaces at increasing scope, frequency and intensity as the key unit of globalisation. ${ }^{11}$ For Ferguson and Mansbach, this transformational interpretation of globalisation best accounts for the proliferation of multi-layered governance institutions across different issue-fields. ${ }^{12}$ They further observe that while these dimensions of globalisation are analytically separable, in practice

\footnotetext{
2 Joseph Stiglitz, Globalisation and its Discontents (2002, Norton and Company) 9.

3 Johannes Urpelainen, 'Regulation Under Economic Globalisation' (2010) 54 International Studies Quarterly 1099, 1101.

4 Kevin O'Rourke and Jeffrey Williamson, 'When Did Globalisation Begin?' (2002) 6 European Review of Economic History 23, 24-25.

5 David Held, Anthony McGrew, David Goldblatt and Jonathan Perraton, 'The Globalisation Debate' in Stuart Hall, David Held and Tony McGrew (eds) Classic Readings and Contemporary Debates in International Relations 3rd ed. (Wadsworth, 2006) 5.

6 Jan Art Scholte, 'Defining Globalisation' (2008) 31 The World Economy 1471, 1474.

7 Above $\mathrm{n} 5$.

8 Above $\mathrm{n} 6$.

9 Ibid., 1477.

10 Ibid., 1478.

11 Ibid., 1479-80.

12 Yale Ferguson and Richard Mansbach, Globalisation: The Return of Borders to a Borderless World? (Routledge, Oxford, 2012) 29.
} 
they often operate collectively. ${ }^{13}$ They qualify this observation by noting that the interdependence between these dimensions of globalisation is likely determined by context, and there may be a lag between the apparent cause and effect of their relative intensity. ${ }^{14}$

Clark cautions against dichotomising globalisation as the transformation of either the state system or the international system. ${ }^{15} \mathrm{He}$ instead argues that the state and international systems are inextricably linked, and that the process of globalisation impinges on both states and the established international framework through the power relations between states. ${ }^{16}$ While this criticism is applicable when considering purely international relations, it discounts the creation of new power relations between state and non-state actors that may serve as alternative avenues for collective action by individuals to influence state decision-making.

Having considered competing definitions of globalisation, I move now to assess the various conceptions of democratisation and their relationship with different frames of globalisation.

\section{Dimensions of democratisation}

Different conceptions of the role of the state within theories of globalisation inform the structure and characteristics of democratisation in a globalised world. This section assesses two competing ideas of democratisation with reference to statecentred and transnational models of globalisation. It concludes that the relationship between globalisation and its democratising effect depends strongly on how it is defined, noting that narrow conceptions of globalisation necessarily limit the scope for assessing democratising traits.

For those who interpret globalisation through the frame of liberal economic internationalisation, the state retains a central position, yet its effects on democratisation are contested. It is suggested that a diminution of state autonomy through increased transnational institutions dilutes the internal democratic authority of the state. In this vein, Cerny argues that the globalisation of economic and political structures undermines the autonomous collective action capacity of states to pursue public goods as preferred within that polity. ${ }^{17} \mathrm{He}$ suggests that the divergence between the structures of territorially bounded states and globalised markets over time will create a disconnect between states' capacity and citizens'

13 Above n 12, 27.

14 Ibid., 28.

15 Ian Clark, Globalisation and International Relations Theory (Oxford University Press, Oxford, 1999) 53.

16 Ibid., 54, 57.

17 Philip Cerny, 'Globalisation and the changing logic of collective action' (1995) 49 International Organisation 595, 596-7. 
expectations, potentially undermining their legitimacy. ${ }^{18}$ Moreover, he argues that for a state to retain these 'classic' public roles it must retain the capacity to shape and control socially significant economic activities. ${ }^{19}$ Thus, for Cerny, the globalisation of markets and the receding independence of state control have direct consequences for states' democratic representative capacity. Hirst and Thompson similarly acknowledge that state autonomy is increasingly constrained within their territory by supranational regulatory bodies that are products and drivers of economic globalisation. ${ }^{20}$ However, they maintain that the nation-state remains the central unit of the international system through their role as regulators for the international economy of labour mobility. ${ }^{21}$ They maintain that this regulatory role is a reframing of their role from government to governance, but one that preserves states' centrality in a complex international system through their nexus with both a body of labour and territory. ${ }^{22}$

Alternative economic approaches to globalisation consider its effect on democratic transition. Milner and Mukherjee assess the relationship between economic globalisation and democratisation through an empirical study of trade and capital account openness as indicators of globalisation. ${ }^{23}$ They find little support in other empirical literature, and form their own analysis for the claim that economic openness encourages democratisation among developing countries. ${ }^{24}$ Similarly, Papaioannou and Siourounis attempt to identify causal factors in third-wave democratisation through an analysis of economic correlates. ${ }^{25}$ As with Urpelainen, O'Rourke and Williamson, these approaches inadvertently privilege state-centric modes of representation to the extent that none others are considered. This approach presents methodological issues for measuring the democratisation potential of simultaneously globalising social and economic spheres.

In contrast to both Cerny's concern that the erosion of state autonomy diminishes its democratic authority and related empirical studies, Held argues that democratic representation increases within networks of institutions and individuals, and ultimately supersedes state-based representation. He argues that there are five disjunctures between globalisation and traditional conceptions of democracy. ${ }^{26}$ Together, these evolving differences between the present and former power structures reflect the diminishing centrality of the state as the autonomous community of

18 Ibid., 598.

19 Ibid., 599.

20 Paul Hirst and Grahame Thompson, Globalisation in Question, 2nd ed. (Polity Press, 1999) 269.

21 Ibid.

22 Ibid., 275.

23 Helen Milner and Bumba Mukherjee, 'Democratisation and Economic Globalisation' (2009) 12 Annual Review of Political Science 163, 164.

24 Ibid.

25 Elias Papaioannou and Gregorios Siourounis, 'Economic and Social factors driving the third wave of democratisation' (2008) 36 Journal of Comparative Economics 365, 366.

26 David Held, Cosmopolitanism: Ideals and Realities (Wiley Publications, 2013) 38. 
individuals with exclusive control over policy choices within it territorial limits. ${ }^{27}$ These transformations, he claims, alter the nature of accountability in national democracies. For Held, democracy in a cosmopolitan order requires traditional ideas of sovereignty to be reconceived from state power over territory to networked spaces of public authority structured through a cosmopolitan legal framework. ${ }^{28}$ By taking democratic politics out of the national sphere and elevating it to decision-making 'conducted in different loci of power' both within and beyond the nation-state, this conception of the democratising power of globalisation allows those in unconsolidated democracies or authoritarian states to potentially bypass undemocratic national governments. Instead, they may seek representation through supranational bodies, and, in doing so, exert reflexive influence on the conduct of their government. Thus, the form of democratisation for Held and other transformationalists need not mirror traditional state-centric structures.

This analysis demonstrates that the relationship between globalisation and its democratising effect depends strongly on how it is defined. Narrow conceptions of globalisation necessarily limit the scope for assessing its democratising traits, while broader transformationalist conceptions acknowledge greater space for the representation of individual and collective interests beyond nation-states. This conclusion suggests that the globalisation of social networks may allow citizens of unconsolidated countries to circumvent authoritarian governments in their pursuit of representation. The next section presents a case study to this effect.

\section{Gezi Park protests: Case study}

In this section, I apply the competing theoretical conceptions of democratisation under globalisation to the case of the 2013 Gezi Park protests in Turkey. Through an analysis of protester demands and the avenues of communication used during this unrest, I begin to evaluate the evidence for norms of transnational or state-based representation against evidence for economic or transformational globalisation. This case has been chosen as it operates at the intersection of Turkish economic globalisation during the global financial crisis, and social trends of Europeanisation in a country with a strong religious/secular divide. ${ }^{29}$ These factors are likely to highlight both economic and transformationalist indicators of globalisation.

29 Fuat Keyman, 'Modernization, Globalisation and Democratisation in Turkey: The AKP Experience and its Limits' (2010) 17 Constellations 312, 318-19. 


\section{Causes of unrest}

The Gezi Park protests began in Istanbul during late May 2013 against the backdrop of the Arab Spring, starting as an environmentalist reaction against the proposed redevelopment of public space into a shopping centre. ${ }^{30}$ This environmental action escalated to mass protests against the incumbent Prime Minister Recep Tayyip Erdogan after aggressive police actions, including the use of tear gas and water cannons to clear non-violent protesters. ${ }^{31}$ The focus of the protest transformed from the redevelopment of public space to concerns about political and human rights ${ }^{32}$ under what was seen as an increasingly authoritarian government. ${ }^{33}$ The protests lasted for two months and involved nearly 3 million people across Turkey, indirectly supported by other acts of civil disobedience. ${ }^{34}$ They culminated in the deaths of six people as a result of violence from both police and protesters. ${ }^{35}$

\section{Protester demands and avenues for expression}

Given the constraints of this project, I have limited my scope to assessing two elements of the protest: the mechanisms of communication used between protesters, and the protester responses to state/non-state representative forums.

In the absence of media coverage of early events, social media allowed for dissemination of protest information, and facilitated the organisation and mass mobilisations seen later. ${ }^{36}$ As many as 67 per cent of protesters reported being informed of the protests by social media, with only 7 per cent being informed by television news. ${ }^{37}$ The relative absence of mainstream reporting of the protests within Turkey likely reflected media self-censorship as a result of state intimidation to reduce coverage critical of the government. ${ }^{38}$ Later in the protest movement, official media outlets were coopted into marginalising the protests by linking them to supposed foreign interests seeking to undermine the Turkish Government. ${ }^{39}$ These dynamics highlight the division between state and transnational power

30 Muge Aknur, 'The Gezi Park protests as a social movement in Turkey: From emergence to coalescence without bureaucratisation’ (2014) 59 Studia Europaea 295, 295.

31 Sermin Tekinalp, 'Rationalization of contradictory cognitive dichotomies versus democracy demands: Istanbul Gezi Park protests' (2016) 28 Rationality and Society 83, 84.

32 Ibid.

33 Ergun Ozbudun, 'AKP at the Crossroads: Erdogan's Majoritarian Drift' (2014) 19 Southern European Society and Politics 155, 157.

34 Hayriye Ozen, 'An unfinished grassroots populism: the Gezi Park Protests in Turkey and their aftermath' (2015) 20 Southern European Society and Politics 533, 533.

35 Muge Aknur, 'The Gezi Park protests as a social movement in Turkey: From emergence to coalescence without bureaucratisation’ (2014) 59 Studia Europaea 295, 296.

36 Above n 34, 541.

37 Coskun Tastan, 'The Gezi Park Protests in Turkey: A Qualitative Field Research' (2013) 15 Insights Turkey 27, 32.

38 Above n 33, 161.

39 Funda Gencoglu Onbasi, 'Gezi Park Protests in Turkey: From “enough is enough” to counter-hegemony?'

(2016) 17 Turkish Studies 272, 274-5. 
structures in the protest. The use of social networks facilitated by communications technology as the dominant form of collective organisation during these protests reflects Castell's conception of the network as an instrument for social change. ${ }^{40}$ Further, this phenomenon aligns with Held's expectations of changing loci of political decision-making away from formal structures to interconnected relationships, allowing them to better articulate preferences through networks at multiple functional levels. Finally, the communication of protests to media outlets outside of Turkey provides some evidence for Scholte's conception of the 'supraterritoriality' and 'transworld instantaneity' of globalised connections. ${ }^{41}$

In spite of the diversity of protesters and their appeals, ${ }^{42}$ the Turkish Government responded with a delegitimising strategy; Prime Minister Erdogan alleging that they were organised by foreign powers in conspiracy against his government. ${ }^{43}$ The aggressive police response and Erdogan's appeal to religious divisions between primarily secular or Kurdish protesters and Islamists affiliated with his ruling party raised concerns of increasing authoritarianism. This pushback against the evolving power structures of the protest movement by the state lends itself to multiple interpretations. Held argues that the actual capacity of states to rule within their territory is changing, thus Erdogan's response may be framed as the state capacity to govern being stretched beyond prior norms. ${ }^{44}$ However, the deliberate appeal to identities of otherness between Islamists and protesters in an attempt to reinforce government support highlights possible weaknesses in the practice of Held's cosmopolitan ideal. The eight principles that he presents as the basis for cosmopolitan social organisation may be readily discarded in self-interested attempts to create identity-based divisions. Nevertheless, the collective experience of the protests' use of communications indicates, at least in part, the development of the causal mechanisms necessary for Held and Schulte's conception of globalised democracy.

An analysis of protesters' political engagement finds qualified support for both Cerny's expectation that economic globalisation may lead to the erosion of statebased democratic authority, and for Held's transformationalist expectation that network-oriented representation may supersede national governments as a forum for democratic expression. The protesters were found to comprise between 41 per cent and 49 per cent opposition party voters, indicating that these individuals had some affiliation with state-centric means of democratic representation. ${ }^{45}$ However, a further 30 per cent of protesters responded that they did not have trust in political institutions and did not vote. ${ }^{46}$ Interviews with members of this demographic

40 Manuel Castells, The Rise of the Network Society, 2nd ed. (Blackwell Publishers, Oxford, 2000), 500.

41 Above n 6, 1480.

42 Above n 34, 535.

43 Above n 35, 296.

44 Above n 26, 37.

45 Above n 37, 28.

46 Ibid., 29. 
reveal a general suspicion of electoral politics, explained by one respondent because 'there are ways to trick the system'. ${ }^{47}$ The respondent identified herself as a Greenpeace activist, possibly indicating that, among some protesters, trust in the representational capacity of non-government organisations (NGOs) was higher than national political avenues. Another respondent stated that 'since imperialist powers are satisfied with this system, nothing will change through elections' ${ }^{48}$ Though he stops short of explaining the mechanism of 'imperialist' influence, the claim highlights common perceptions that national political legitimacy is readily undermined by real or perceived external forces. These concerns broadly align with the causal mechanisms described by both Cerny's expectation that economic globalisation may lead to the erosion of state-based democratic authority, and Held's transformationalist expectation that network-oriented representation may supersede national governments as a forum for democratic expression.

From this brief analysis of the Gezi Park protests, I draw mixed support for the democratisation thesis associated with both the economic and the transformationalist models of globalisation. Expanding on observations presented in this section, I go on to provide a critical reflection on the limits of the finding that accountable decision-making in distributed power structures arise under a transformationalist model of globalisation.

\section{Ways forward: Representation in the age of the global}

The above analysis finds qualified evidence that globalisation has increased the scope for representation of individual and collective interests beyond state governments. Yet it is necessary to develop new approaches to public accountability for their democratising power to be fully realised. This section makes a brief contribution to that task.

Moore provides guidance on democratisation in a globalised order by considering competing institutional designs of democratic representation. ${ }^{49}$ She presents a dichotomy of a 'demos-creating' unitary structure corresponding closely with expectations of state-based mechanisms of representations, ${ }^{50}$ and a pluralist non-territorial model describing mechanisms of representation that align with a transformationalist understanding of globalisation. ${ }^{51}$ Under the pluralist non-

47 Ibid.

48 Ibid., 30.

49 Margaret Moore, 'Globalisation and Democratisation: Institutional Design for Global Institutions' (2006) 37

Journal of Social Philosophy 21, 21.

50 Ibid., 24.

51 Ibid. 
territorial model, policies draw legitimacy from moral cosmopolitanism based on a principle of fairness to others, ${ }^{52}$ and this does not require a territorially defined demos. Yet she finds that this structure lacks accountability between decision-makers and the represented. In response, Moore presents an adapted model of Lijphart's consociational democracy as an ideal type for transnational decision-making. ${ }^{53}$ This concern for accountability highlights potential shortcomings in the transnational networked model of democracy promoted as part of transformationalist globalisation. Yet, the proposed approach falls short of a solution, neglecting the distributed and decentralised decision-making process that is likely under a pluralist non-territorial form of democracy. While Held also acknowledges the requirement for accountability of decisions made within a cosmopolitan framework, ${ }^{54}$ in practice the above case study highlights countervailing pressures.

As a partial solution, I suggest that the four rules of consociational democracy may be embedded as cultural or behavioural norms within those distributed networks, increasing 'soft' avenues for accountability. The four rules as presented by Moore include:

i. The expectations of cross community executive power sharing

ii. proportionality rules throughout the governmental and public sectors

iii. self-government or political autonomy

iv. and veto rights for minorities so that each is able to prevent changes that adversely affect their vital interests. ${ }^{55}$

If adopted as norms within the distributed networks of representation, these rules would create pressures towards accountability and fairness that are otherwise lacking within those associations.

\section{Conclusion}

This article argued that while different conceptions of globalisation increase avenues for political representation and engagement that depart from the traditional national/representative model, these forums require reform to deliver their democratising potential. In analysing existing literature, it found strongly contested definitions of globalisation and democratisation. It also found, however, that conceptual developments in the globalisation literature erode traditional conceptions of state-centric democratisation, yet create opportunities for greater transnational representation of individual preferences. This effect operates

53 Ibid., 37.

54 Above n 26, 69.

55 Ibid. 
through a transformationalist understanding of globalisation and the concurrent development of networked systems of representation. The article assessed conceptions of democratisation against the case study of Turkey's 2013 Gezi Park protests, focusing on the representational power of distributed and state-based democratic institutions. Finally, it briefly developed on themes identified in the case study, arguing that while globalisation has increased the scope for representation of individual and collective interests beyond state governments, it is necessary to develop new approaches to public accountability for their democratising power to be fully realised. Through this analysis, it concludes that a transformationalist understanding of globalisation presents new, though imperfect, mechanisms for democratising political interactions.

\section{Bibliography}

Aknur, Muge. (2014). 'The Gezi Park Protests as a Social Movement in Turkey: From Emergence to Coalescence without Bureaucratisation' Studia Europaea 59(1), 295-320.

Castells, Manuel. (2000). The Rise of the Network Society (2nd ed.). Oxford: Blackwell Publishers.

Cerny, Philip. (1995). 'Globalisation and the Changing Logic of Collective Action'. International Organisation, 49(4), 595-625. doi: 10.1017/S0020818300028459

Cerny, Philip. (2009). 'Multi-nodal Politics: Globalisation is what Actors Make of It'. Review of International Studies, 35(2), 421-449.

Clark, Ian. (1999). Globalisation and International Relations Theory. Oxford: Oxford University Press.

Ferguson, Yale and Richard Mansbach (2012). Globalisation: The Return of Borders to a Borderless World? Oxford: Routledge.

Grugel, Jean and Nicola Piper. (2007). Critical Perspectives on Global Governance: Rights and Regulation in Governing Regimes. Oxford: Routledge.

Grugel, Jean (2003). 'Democratisation studies Globalisation: the coming of age of a paradigm'. British Journal of Politics and International Relations, 5(2), 258283.

Held, David, Anthony McGrew, David Goldblatt and Jonathan Perraton. (2006). 'The Globalisation Debate'. In Stuart Hall, David Held and Tony McGrew (eds), Classic Readings and Contemporary Debates in International Relations (3rd ed.). Wadsworth. 
Hirst, Paul and Grahame Thompson. (1999). Globalisation in Question (2nd ed.). Polity Press.

Kaldor, Mary. (2003). Global Civil Society: An Answer to War. Cambridge: Polity Press, Cambridge.

Kaldor, Mary. (2013). Human Security. Polity Press.

Keyman, Fuat. (2010). 'Modernization, Globalisation and Democratisation in Turkey: The AKP Experience and its Limits'. Constellations, 17(12), 312-327. doi: 312.10.1111/j.1467-8675.2010.00596.x

Milner, Helen and Bumba Mukherjee. (2009). 'Democratisation and Economic Globalisation'. Annual Review of Political Science, 12, 163-181.

Moore, Margaret. (2006). 'Globalisation and Democratisation: Institutional Design for Global Institutions'. Journal of Social Philosophy, 21, 163-181. doi. org/10.1146/annurev.polisci.12.110507.114722

Onbasi, Funda Gencoglu. (2016). 'Gezi Park Protests in Turkey: From "Enough is Enough"' to Counter-Hegemony?' Turkish Studies, 17, 272-294. dx.doi.org/10. $1080 / 14683849.2016 .1165615$

O'Rourke, Kevin and Jeffrey Williamson. (2002). 'When did Globalisation Begin?' European Review of Economic History, 6(1), 23-50. doi: 10.3386/w7632

Ozbudun, Ergun. (2014). 'AKP at the Crossroads: Erdogan's Majoritarian Drift'. Southern European Society and Politics, 19(2), 155-167. dx.doi.org/10.1080/13 608746.2014.920571

Ozen, Hayriye. (2015). 'An Unfinished Grassroots Populism: The Gezi Park Protests in Turkey and their Aftermath'. Southern European Society and Politics, 20(4), 533-552. dx.doi.org/10.1080/13608746.2015.1099258

Papaioannou, Elias and Gregorios Siourounis. (2008). 'Economic and Social Factors Driving the Third Wave of Democratisation'. Journal of Comparative Economics, 36, 365-387.

Scholte, Jan Aart. (2008). 'Defining Globalisation'. The World Economy, 31(11), 1471-1502. doi: 10.1111/j.1467-9701.2007.01019.x

Stiglitz, Joseph. (2002). Globalisation and its Discontents. Norton \& Company.

Tastan, Coskun. (2013). 'The Gezi Park Protests in Turkey: A Qualitative Field Research'. Insights Turkey, 15(3), 27-38. 
Tekinalp, Sermin. (2016). 'Rationalization of Contradictory Cognitive Dichotomies Versus Democracy Demands: Istanbul Gezi Park Protests'. Rationality and Society, 28(1), 83-104.

Urpelainen, Johannes. (2010). 'Regulation Under Economic Globalisation'. International Studies Quarterly 54(4), 1099-1121. doi: 10.1111/j.14682478.2010.00628.x

Wendt, Alexander. (2003). 'Why a World State is Inevitable'. European Journal of International Relations, 9(4), 491-542. 
This text is taken from The ANU Undergraduate Research Journal, Volume Eight, 2016, edited by Daniel McKay, published 2017 by ANU eView, The Australian National University, Canberra, Australia.

dx.doi.org/10.22459/AURJ.08.2016.16 